\title{
ANALISIS SEGMENTASI PASAR SAYURAN ORGANIK DI PULAU SAPARUA KABUPATEN MALUKU TENGAH
}

\author{
Valenszya Jozias, Natelda R. Timisela*, Marfin Lawalata \\ Program Studi Agribisnis, Fakultas Pertanian, Universitas Pattimura \\ Jl. Ir. M. Putuhena, Kampus Poka, Ambon 97233 \\ *Corresponding author: nateldatimisela@yahoo.com
}

\begin{abstract}
This research aims to determine the segmentation of the organic vegetable market. The research sample consisted of farmers and organic vegetable traders taken by a census of 13 respondents. While the consumer sample is taken by chance, the accidental sample is 40 respondents. The final cluster analysis results show that cluster 1, the Z-score is negative, that is, age and work, and in cluster 2, the Z-score is negative, namely education and income. This means that in cluster 1, consumers' age and occupation are still very minimal to determine choices in choosing organic vegetables for consumption. The same thing also happened in cluster 2, education and consumer income is still low to choose organic vegetables as consumer needs. The most considerable $F$ value $(56,156)$ is seen in the Z-score of education, with a significant number of 0,000, which means the significance is real. This means that educational factors significantly distinguish the characteristics of the two clusters. Or in other word, education in the two clusters is very different between cluster 1 and cluster 2.
\end{abstract}

Keywords: segmentation, organic vegetables, cluster, Z-score, Saparua island.

\begin{abstract}
Abstrak: Penelitian ini bertujuan untuk mengetahui segmentasi pasar sayuran organik. Sampel penelitian terdiri dari petani dan pedagang sayuran organik diambil secara sensus berjumlah masing-masing 13 responden. Sedangkan sampel konsumen diambil secara insidental yaitu pengambilan sampel secara kebetulan berjumlah 40 responden. Hasil analisis final cluster menunjukkan bahwa klaster 1, Z-score bernilai negatif yaitu usia dan pekerjaan, pada klaster 2, Z-score bernilai negatif yaitu pendidikan dan pendapatan. Hal ini berarti bahwa pada klaster 1, usia dan pekerjaan konsumen masih sangat minim untuk menentukan pilihan dalam memilih sayuran organik untuk dikonsumsi. Hal yang sama juga terjadi di klaster 2, pendidikan dan pendapatan konsumen masih rendah untuk memilih sayuran organik sebagai kebutuhan konsumen. Nilai $\mathrm{F}$ terbesar $(56,156)$ terlihat pada Z-score pendidikan, dengan angka signifikan 0,000 yang berarti signifikansinya adalah nyata. Hal ini berarti faktor pendidikan sangat membedakan karakteristik kedua klaster. Atau dapat dikatakan bahwa pendidikan pada kedua klaster yang sangat berbeda antara klaster 1 dengan klaster 2.
\end{abstract}

Kata Kunci: segmentasi, sayuran organik, klaster, Z-score, Pulau Saparua.

\section{PENDAHULUAN}

Sayuran dan buahan merupakan komoditi hortikultura yang memiliki kandungan serat, mineral dan vitamin yang diperlukan tubuh manusia. Sayuran dapat memberikan manfaat besar untuk meningkatkan pendapatan dan kesejahteraan masyarakat, memiliki keunggulan secara ekonomis dan mudah dibudidayakan. Seseorang harus makan sayur sebanyak 200 gram per hari untuk menjaga metabolisme tubuh. Komoditi hortikultura merupakan komoditi yang paling prospek, karena komoditi hortikultura memiliki umur 
yang pendek, permintaan tinggi, dan peluang pasarnya besar (Bina, 2014).

Semua bahan pangan yang diproduksi dengan menggunakan bahan-bahan alami disebut pangan organik, karena ramah lingkungan, bebas pestisida dan pupuk kimia yang dapat merusak struktur tanah dan mencemari air serta udara. Menurut Manuhutu (2005) senyawa kimia sangat berbahaya bagi tubuh manusia karena dapat merusak kerja saraf, mengganggu metabolism tubuh, menyebabkan kanker, menganggu kecerdasan, menimbulkan radikal bebas, penggunaan dengan dosis tinggi dapat menyebabkan kematian dan meningkatkan resiko keguguran pada ibu hamil.

Salah satu pangan organik yang sangat berpengaruh terhadap kehidupan manusia adalah sayuran organik. Peluang untuk mengusahakan sayuran organik sangat besar karena masyarakat mulai sadar bahwa mengkonsumsi sayuran yang bebas bahan kimiawi dapat meningkatkan daya tahan tubuh dan terbebas dari racun. Manfaat sayuran organik antara lain: sayuran organik memiliki $50 \%$ lebih banyak antioksidan, menurunkan resiko penyakit kanker dan jantung serta mengandung mineral seperti zat besi dan zink dan vitamin. Menurut Saragih (2008) terdapat lima sumberdaya yang dapat diperbaiki melalui pertanian organik seperti sumberda daya alam, manusia, sosial, ekonomi dan infrastruktur.

Petani organik di Kecamatan Saparua dan Saparua Timur berkembang dengan baik. Salama ini, kajian tentang usahatani sayuran organik lebih banyak di Pulau Ambon. Perkembangan usahatani sayuran organik di Pulau Saparua sudah dilaksanakan mulai tahun 2015, akan tetapi sampai dengan saat ini belum ada kajian mengenai pengembangannya. Luas lahan sayuran di Pulau Saparua sebesar 141 hektar dengan jumlah produksi 468,9 ton Dinas Pertanian dan Peternakan Kabupaten Maluku Tengah (2015). Petani dalam pengembangan usahatani sayuran awalnya membudidayakan sayuran non organik, seiring berkembangnya waktu karena sayuran organik mulai diminati maka petani di Pulau Saparua mencoba membudidayakan sayuran organik. Hasil panen cukup memuaskan bagi petani, karena banyak konsumen yang mulai melirik sayuran organik untuk konsumsi sehari-hari.
Muljaningsih (2011) dalam penelitiannya mengemukakan bahwa produk organik dari hulu ke hilir pergerakannya lambat. Faktor ekonomi dan faktor sosial mendominasi preferensi konsumen dan produsen. Variabel usia dan pendidikan berkorelasi negatif dengan preferensi konsumen, namun variabel kesehatan mempunyai korelasi negatif menurut preferensi produsen. Preferensi konsumen terhadap beras, buah, dan sayuran organik adalah baik untuk kesehatan, tetapi keluhannya produk lebih mahal. Preferensi produsen terhadap produk organik beras, buah, dan sayuran harus mempunyai sertifikat. Preferensi konsumen tidak dibatasi usia dan pendidikan, sedangkan preferensi produsen masih tidak memahami manfaat kesehatan dari produk organik.

Sayuran organik banyak diminati oleh masyarakat karena masyarakat mulai mengerti arti hidup sehat dengan mengkonsumsi produkproduk organik. Kebutuhan masyarakat terus meningkat seiring dengan pertambahan jumlah penduduk dan daya belinya (Timisela et al., 2018). Penelitian Ravindra (2017) menyatakan bahwa segmenting berpengaruh secara signifikan terhadap keputusan kembelian, dengan memiliki segmenting yang baik dalam menggolongkan (segmentasi) pasar. Dapat dikatakan secara umum perusahaan mempunyai motivasi untuk mempertahankan dan meningkatkan tingkat penjualan dan yang lebih penting lagi agar operasi perusahaan dalam jangka panjang dapat berkelanjutan dan kompetitif sehingga meningkatkan keputusan konsumen untuk melakukan pembelian.

Pemetaan segmentasi pasar dari konsumen sayuran organik di Pulau Saparua belum pernah dikaji, padahal saat ini perhatian terhadap sayuran organik semakin meningkat. Petani penghasil dan pedagang sayuran organik perlu memetakan segmentasi pasar. Pembagian pasar berdasarkan kelompok konsumen sesuai dengan kebutuhan atau karakterisitik dan memilih satu atau beberapa segmen yang menjadi target pasar.

Mengidentifikasi dan memutuskan segmen yang dibidik merupakan tugas pemasar. Selain itu, untuk menentukan strategi pemasaran yang efektif dan efisien maka segmentasi penting sebagai data pendukung bagi produsen. Melalui segmentasi dapat mencegah penurunan penjualan sayuran 
organik karena telah ada kejelasan target pasar yang akan dituju. Tujuan penelitian ini adalah untuk menganalisis segmentasi pasar sayuran organik di Pulau Saparua.

\section{METODE PENELITIAN}

Penelitian dilaksanakan di Pulau Saparua, Kabupaten Maluku Tengah. Pemilihan lokasi secara sengaja karena terdapat dua pasar sebagai target penjualan sayuran organik yaitu Pasar Nolot dan Pasar Saparua Kota. Penelitian menggunakan metode survei yaitu penyelidikan dan pengamatan yang kritis terhadap keterangan yang jelas untuk sebuah persoalan atau informasi. Metode penelitian yang memakai kuesioner sebagai intrumen pengumpulan data adalah metode survei (Kriyantono, 2006).

Metode pengambilan sampel petani dan pedagang sayuran organik dilakukan secara sensus. Jumlah sampel petani dan pedagang masing-masing 13 responden. Pengambilan sampel konsumen secara incidental yaitu pengambilan sampel secara kebetulan yakni pada saat peneliti bertemu dengan konsumen di pasar dan konsumen bersedia untuk diwawancarai (Sugiyono, 2018). Jumlah sampel konsumen sebanyak 40 responden. Analisis secara deskriptif digunakan untuk data target pasar, sedangkan analisis data yang digunakan untuk segmentasi pasar adalah $k$ means clustering.

$\mathrm{D}(i, j)=\sqrt{ }\left(X_{l i}-X_{l j}\right)^{2}+\left(X_{2 i}-X_{2 j}\right)^{2}+\ldots+\left(X_{k i}-X_{k j}\right)^{2}$

Keterangan:

$\mathrm{D}(i, j)=$ Jarak data ke $i$ ke pusat klaster $j$

$X_{k i} \quad=$ Data ke $i$ pada atribut data ke $k$

$X_{k j} \quad=$ Titik pusat ke $j$ pada atribut ke $k$

\section{HASIL DAN PEMBAHASAN}

\section{Karakteristik Responden}

Karakteristik responden dalam penelitian ini meliputi pendidikan, jumlah anggota keluarga dan umur. Kemampuan seseorang dalam menjalankan usahanya tergantung pada umur orang tersebut. Kategori umur terdiri dari tiga bagian yaitu umur belum produktif (0-14 tahun), umur produktif (15-64 tahun) dan tidak produktif (> 64 tahun).
Menurut Sukmaningrum dan Imron (2017) seseorang yang belum mampu menghasilkan barang ataupun jasa dalam kegiatan ketenagakerjaan dikategorikan sebagai umur belum produktif. Jika seseorang dianggap mampu untuk bekerja dan menghasilkan barang dan jasa yang dibutuhkan oleh orang lain dalam sebuah proses produksi dikategorikan sebagai umur produktif. Namun, jika orang tersebut sama sekali tidak mampu untuk bekerja dan hidupnya ditanggung oleh orang lain dikategorikan sebagai umur tidak produktif.

Data BKKBN (2014) menyatakan bahwa seseorang dianggap produktif ketika mempunyai andil yang besar dalam kegiatan ketenagakerjaan. Orang itu mampu bekerja semaksimal mungkin karena harus menanggung orang yang belum produktif bahkan tidak produktif. Orang berusia diatas 20 tahun tergolong usia produktif karena telah selesai bersekolah, selain itu remaja usia muda yang bersekolah tetapi memiliki pekerjaan biasanya dijumpai di daerah perkotaan. Kaum muda bekerja sebagai tenaga pembantu dalam usaha keluarga sampai mereka memiliki pekerjaan sendiri.

Hasil penelitian menunjukkan bahwa umur menentukan seseorang aktif dalam bekerja dan ketersediaan tenaga kerja dalam sebuah usaha sangat tergantung pada umur. Tenaga kerja merupakan salah satu aset penting dari suatu usaha tani karena proses produksi hanya bisa dihasilkan jika ada pekerja yang mengerjakannya. Pekerja yang diperhitungkan adalah pekerja dengan usia produktif yaitu 1564 tahun. Tabel 1 menampilkan karakteristik responden berdasarkan umur.

Tabel 1 memperlihatkan kategori umur responden semuanya berada pada kondisi umur produktif berarti bahwa semua responden mempunyai kemampuan dan kekuatan fisik yang baik untuk bekerja dan menghasilkan barang dan jasa. Petani sebagai penghasil sayuran organik memiliki kemampuan fisik yang baik untuk mengembangkan kegiatan usahataninya. Petani dibekali dengan kemampuan ekstra untuk bekerja secara kontinu dan menghasilkan sayuran organik yang aman untuk dijual oleh pedagang dan dikonsumsi oleh konsumen. 
Jozias, V., Timisela, N. R., Lawalata, M. : Analisis Segmentasi Pasar Sayuran Organik ...

Tabel 1. Karakteristik Responden Berdasarkan Umur, Pendidikan dan Jumlah Anggota Keluarga

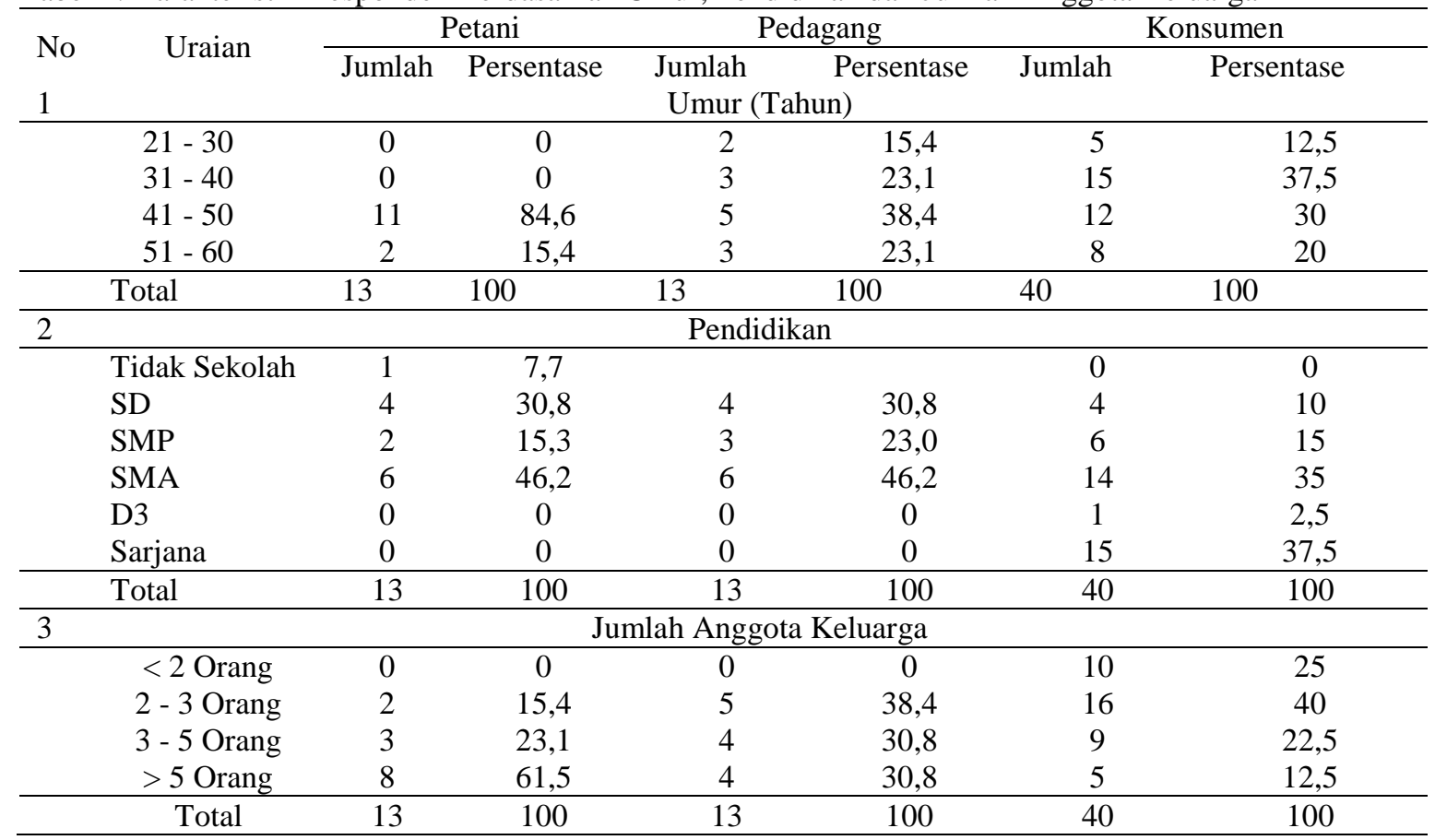

Sumber: Analisis Data Primer, 2019

Pedagang sebagai orang yang berjualan di pasar juga memiliki kemampuan dan kekuatan fisik yang baik untuk bekerja. Pekerjaan sehari-hari sebagai pedagang membutuhkan kemampuan ekstra untuk melakukan berbagai aktivitas berdagang di pasar. Pedagang yang menjual sayuran organik berjumlah 13 orang, berarti 13 orang inilah yang setiap saat membeli sayuran organik dari petani sayuran organik di Pulau Saparua. Responden konsumen adalah orang yang sehari-hari ke pasar untuk membelanjakan uangnya guna mendapatkan barang dan jasa yang diinginkan. Terlihat bahwa terdapat 40 responden yang selalu membeli sayuran organik dari pedagang di Pasar Nolot dan Pasar Saparua.

Penentuan sikap dan pola pikir seseorang sangat tergantung pada tingkatan pendidikan. Hal ini juga berkaitan dengan pola konsumsi pangan, kandungan gizi dan pola pemberian makanan. Pemilihan makanan yang murah tetapi kandungan gizinya tinggi cenderung dicari oleh orang yang berpendidikan tinggi (Suhardjo, 1996). Tabel 1 menampilkan tingkat pendidikan responden.

Tingkat pendidikan petani penghasil sayuran organik dan pedagang adalah mulai dari tidak sekolah sampai tamat SMA. Hal ini berarti bahwa pendidikan tidak menjadi kendala bagi seseorang dalam mengembangkan dirinya dengan kegiatan-kegiatan yang bermanfaat seperti budidaya sayuran organik dan menjual sayuran organik. Petani rata-rata memperoleh ilmu dan pengetahuan tentang budidaya sayuran organik dari teman, LSM dan akadmisi perguruan tinggi.

Sebagian besar responden belajar otodidak dan beberapa responden dibimbing oleh LSM dan Akademisi untuk menjadi lebih pandai dalam membudidayakan sayuran organik. Pendidikan formal tidak menjadi tumpuan utama untuk belajar tentang budidaya sayuran organik, tetapi pendidikan non formal menjadi kekuatan bagi petani untuk belajar lebih banyak lagi dan mempraktekan semua ilmu dan pengetahuan yang dimiliki untuk budidaya sayuran organik.

Pedagang sebagai penadah di pasar yang sehari-hari menjajakan semua hasil jualannya kepada konsumen. Mereka tidak membutuhkan pendidikan tinggi, tetapi mereka pandai untuk menghitung untung rugi dan strategi penjualan yang baik untuk mendapatkan keutungan dalam berdagang. Berbeda dengan konsumen, tingkat pendidikan konsumen mulai dari SD sampai dengan Sarjana. Konsumen dengan tingkat pendidikan SMA dan Sarjana lebih banyak 
membeli sayuran organik karena mereka lebih banyak mengetahui kegunaan sayuran organik bagi kesehatan. Berbeda dengan responden yang berpendidikan SD, SMP dan D3 presentase pembelian sayuran organik lebih rendah karena belum banyak mengetahui manfaat mengkonsumsi sayuran organik.

Faktor yang mempengaruhi kondisi kehidupa ekonomi keluarga adalah jumlah anggota keluarga karena secara langsung berkaitan dengan konsumsi dalam rumahtangga tersebut, baik konsumsi pangan maupun non pangan Todaro dan Michael P (1998). Tabel 1 menampilkan karakteristik responden berdasarkan jumlah anggota keluarga. Jumlah anggota keluarga petani dan pedagang beragam mulai dari 2-3 orang sampai $>5$ orang. Sedangkan konsumen dengan jumlah anggota keluarga $<2$ orang sampai $>5$ orang.

Jumlah anggota keluarga berkaitan ketersediaan tenaga kerja dalam keluarga untuk membantu petani atau pedagang dalam melakukan aktivitas usahatani sayuran organik atau aktivitas berjualan di pasar. Kebanyakan ketersediaan anggota keluarga yang produktif akan sangat membantu meringankan pekerjaan dalam keluarga untuk aktivitas usahatani sayuran organik atau kegiatan berdagang. Jumlah anggota keluarga untuk responden konsumen berkaitan dengan jumlah pengeluaran rumah tangga untuk mengadakan bahan-bahan kebutuhan konsumsi.

Petani memiliki jumlah angota keluarga terbanyak yaitu $>5$ orang sebanyak $61,5 \%$ sedangkan pedagang dan konsumen rata-rata memiliki jumlah anggota keluarga 2-3 orang sebesar $38.4 \%$ dan $40 \%$. Perbedaan ini wajar terjadi karena petani melakukan aktivitas pertanian cenderung membutuhkan tenaga kerja dalam keluarga untuk membantu meringankan beban kerjanya sehingga kelebihan anggota keluarga dapat dimanfaatkan untuk membantu di lahan usahatani sayuran organik. Sedangkan pedagang dan konsumen kebanyakan hanya memiliki satu orang anak yang jarang dijadikan sebagai tenaga kerja untuk membantu pekerjaan dalam rumah tangga.

\section{Produksi}

Proses barang dan jasa sebagai input diubah menjadi barang dan jasa lain sebagai output disebut produksi. Jenis kegiatan dalam proses produksi antara lain perubahan tempat, waktu, bentuk dan kegunaan. Perubahan yang akan terjadi tergantung pada penggunaan input untuk menghasilkan output yang bermanfaat. Menurut Sudarman (1999) produksi meliputi penciptaan barang dan jasa. Menurut Sukirno (2008) produksi merupakan kegiatan untuk memperoleh output dengan memakai teknik produksi tertentu untuk memproses atau mengolah input yang tersedia.

Sayuran organik saat ini merupakan sayuran yang berkualitas dan sehat sekaligus sayuran organik menjadi pelengkap gizi bagi tubuh masyarakat. Produksi sayuran organik yang terus meningkat menunjukan bahwa masyarakat mulai peduli dengan kesehatan mereka. Oleh sebab itu, target pasar perlu ditentukan untuk keberlangsungan proses pemasaran sehingga produsen lebih mudah dalam memproduksi tuntutan kebutuhan serta keinginan dari target pasar. Pedagang yang menjual sayuran organik dan konsumen yang mengkonsumsi sayuran organik merupakan target pasar. Konsumen yang mengkonsumsi sayuran organik adalah golongan masyarakat dengan gaya hidup yang berbeda.

$\underline{\text { Tabel 2. Produksi Sayuran Organik di Pulau Saparua (kg/musim tanam) }}$

\begin{tabular}{lllccc}
\hline \multirow{2}{*}{ No. } & \multirow{2}{*}{ Jenis sayuran } & \multicolumn{3}{c}{ Desa } & \multirow{2}{*}{ Total } \\
\cline { 3 - 4 } & & \multicolumn{2}{c}{ Nolot } & Haria & \multicolumn{1}{c}{ Mahu } \\
\hline 1 & Kacang panjang & $129,97(30,24)$ & & $299,8(69,76)$ & 429,77 \\
2 & terong & $93,79(100)$ & & 93,79 \\
3 & Sakata & & $119,98(23,08)$ & $399,92(76,92)$ & 519,9 \\
4 & Bayam & & $29,99(100)$ & 29,99 \\
5 & Kangkung & & $65,93(29,85)$ & $154,96(70,15)$ & 220,89 \\
6 & Sawi & $30(23,11)$ & $99,8(76,89)$ & 129,8 \\
7 & Timun & & & $700(100)$ & 700 \\
\hline
\end{tabular}

Sumber: Analisis Data Primer, 2019 
Penggunaan sejumlah input dalam usahatani untuk menghasilkan output yang dibutuhkan, dimana produksi sebagai tolak ukur untuk mengukur tingkat keberhasilan petani dalam usahataninya. Mubyarto dalam Perdana (2016) menyatakan bahwa produksi yang tinggi merupakan langkah sukses dalam keberhasilan usahatani. Tabel 2 memperlihatkan bahwa petani di Nolot memproduksikan kacang panjang dan terong. Terlihat bahwa memiliki persentase produksi kacang panjang sebesar 30,24\% lebih sedikit dibandingkan Mahu 69,76\%. Terong hanya dihasilkan di Desa Nolot karena desa lain tidak memproduksi terong. Petani Desa Nolot memulai usahatani sayuran organik tahun 2019, masih terbilang baru sehingga belum banyak jenis sayuran yang diusahakan dan produksi masih relatif sedikit. Selain itu petani belum banyak melaksanakan kegiatan usahatani sayuran organik karena mereka masih harus belajar dari desa tetangga, akan tetapi hasil panen sayuran organik cukup untuk memenuhi permintaan konsumen yang belum terlalu tinggi.

Petani di Desa Haria memproduksikan sayuran organik seperti sakata, bayam, kangkung dan sawi. Persentase tertinggi untuk sayuran organik yang diusahakan yaitu bayam sebesar 100\%. Petani Haria mengusahakan bayam secara kontinu sehingga produksi meningkat sementara desa lainnya tidak mengusahakan bayam. Kangkung menempati produksi tertinggi kedua setelah bayam dengan persentase sebesar 29,85\%. Petani Desa Haria memulai usahatani sayuran organik dari tahun 2015 namun tidak kontinu dan tersebar di banyak tempat sehingga produksi sayuran organik tidak menentu.

Permintaan sayuran sakata di Pulau Saparua sangat tinggi karena kebanyakan konsumen lebih memilih mengkonsumsi sayur sakata organik. Berbeda dengan petani Desa Mahu memulai usahatani sayuran organik tahun 2016 dengan jumlah produksi sayuran sakata terbesar yaitu $76,92 \%$. Jenis sayuran organik lain yang diusahakan yaitu kangkung $(70,15 \%)$, sawi $(76,89 \%)$, kacang panjang $(69,76)$, dan timun $(100 \%)$. Timun hanya dihasilkan petani Mahu di Pulau Saparua sehingga produksinya relatif tinggi. Jenis-jenis sayuran organik yang diusahakan oleh petani
Mahu secara kontinu sehingga produksi terus mengalami peningkatan.

\section{Target Pasar}

Sekumpulan konsumen sebagai sasaran perusahaan untuk membeli produk yang dijual dikenal dengan target pasar. Pengelompokkan kosumen ke dalam kelompok dengan ciri-ciri atau sifat yang hampir sama merupakan tujuan target pasar. Target pasar merupakan sekelompok orang yang menjadi target penjualan produk. Umumnya, target pasar akan memiliki karakteristik yang sama baik dari sisi kebiasaan, demografi, dan lainnya. Dengan kata lain, target pasar adalah calon pembeli potensial yang harus mendapatkan informasi dan promosi terkait produk, sehingga produsen harus mengupayakan langkah yang tepat untuk menjangkau konsumen dengan baik untuk membuat konsumen membeli produk tersebut.

Hasil panen petani hasil sayuran organik langsung dijual ke pedagang di pasar yakni Pasar Nolot dan Pasar Saparua. Kedua pasar ini menjadi bidikan petani sayuran organik karena ramai dikunjungi oleh konsumen. Kedua pasar terletak di dua kecamatan yakni Pasar Nolot di Kecamatan Saparua Timur dan Pasar Saparua di Kecamatan Saparua. Target pasar pada Pasar Saparua dan Pasar Nolot menerapkan target konsumen berdasarkan aspek usia, pendidikan, pekerjaan dan pendapatan.

Usia menjadi penentu target seseorang untuk membeli produk. Konsumen sayuran organik berusia 21-64 tahun. Berdasarkan umur, terlihat bahwa sayuran organik dianggap sebagap sebagai produk sehat karena dibudidayakan dengan metode alamiah yakni memanfaatkan bahan alami yang ada di desa. Petani tidak menggunakan bahan kimiawi untuk budidaya sayuran organik sehingga konsumsi sayuran organik aman dan terpercaya. Target pasar yang dibidik petani dan pedagang di Pasar Saparua dan Pasar Nolot yakni konsumen berusia 31-40 termasuk tahapan usia dewasa (Zimbardo, 2000). Usia ini, biasanya individu mengalami transisi yang serius menyangkut penentuan tujuannya. Biasanya individu lebih fokus pada keluarga dan pengembangan karier.

Tingkat pendidikan menjadi pertimbahan konsumen dalam memilih produk untuk dikonsumsi. Sayuran organik paling diminati oleh konsumen dengan latar belakang SD, 
SMP, SMA, Sarjana bahkan ada konsumen yang tidak bersekolah. Terlihat bahwa latar belakang pendidikan konsumen tidak menjadi penghalang untuk mengkonsumsi sayuran organik. Target pasar yang dibidik petani maupun pedagang di Pasar Saparua dan Pasar Nolot adalah konsumen yang berpendidikan SMA.

Pekerjaan seseorang menentukan tingkat kemampuannya untuk membeli sebuah produk. Status pekerjaan konsumen sayuran organik beragam antara lain: Wirausaha, PNS, Honorer, dan ibu rumah tangga. Petani tetap melakukan aktivitas produksi sayuran organik secara kontinu. Pedagang tetap melakukan aktivitas berdagang sayuran organik yang dibeli dari petani. Konsumen sebagai pembeli di pasar, apapun pekerjaannya tidak mempengaruhi aktivitas petani dan pedagang dalam berusaha. Petani dan pedagang terus berusaha untuk menarik perhatian konsumen untuk membeli sayuran organik. Target pasar berdasarkan jenis pekerjaan konsumen yang mengkonsumsi sayuran organik adalah konsumen yang bekerja sebagai wirausaha. Hal ini dikarenakan wirausaha lebih banyak membeli sayuran organik di Pasar Nolot maupun Pasar Saparua.

Tingkat pendapatan menjadi pertimbangan seseorang untuk membelanjakan uangnya guna mendapatkan barang dan jasa. Konsumen yang berpendapatan menengah ke atas akan memilih barang-barang yang baik. Namun di daerah pedesaan, pendapatan seseorang bukan jaminan bahwa konsumen akan memiliki barang bagus dan bermerek. Target pasar berdasarkan tingkat pendapatan konsumen di Pasar Nolot dan Pasar Saparua adalah konsumen yang berpendapatan $<\mathrm{Rp}$. 2.000.000. Seseorang dengan tingkat pendatapan menengah ke atas biasanya menunjukkan pekerjaan dan tingkat kesibukan yang beragam. Segmen ini menjadi rasionalisasi yang dominan untuk motif pembelian utilitarian yang berorientasi kognitif, tugas dan rasional dengan kemauan atau keinginan agar dapat membeli produk yang efisien dan rasional (Babin et al, dalam Kang et al., 2010). Menurut Lamb et al. (2001) bahwa seseorang dengan daya beli tinggi ditentukan oleh tingkatan pendapatan yang ikut mempengaruhi keinginan dan penentuan daya beli konsumen.

\section{Segmentasi Pasar}

Pengelompokkan target pasar berdasarkan lokasi atau wilayah merupakan segmentasi. Tujuan segementasi adalah mengetahui hubungan target pasar, diahrapkan setiap wilayah memiliki kebutuhan yang berbeda dan dicocokkan dengan karakter produk atau merek. Segmentasi terdiri dari beberapa jenis namun yang diteliti dalam penelitian ini adalah segmentasi demografi dan geografi. Segementasi demografi sangat mendasar dan penting untuk pembuatan target pasar. Dalam pengelompokkan seperti tingkat pendidikan, usia, jenis kelami dan pendapatan dengan tujuan untuk mengetahui produk atau mereka yang cocok untuk dipasarkan.

Analisis segmentasi pasar terhadap sayuran organik di Pulau Saparua meliputi segmentasi demografis dan segmentasi geografis. Segmentasi demografis yaitu meliputi: usia, tingkat pendidikan, pekerjaan dan pendapatan. Segmentasi geografis ditujukan untuk membagi pasar menurut unit geografi seperti: negara bagian, negara, propinsi, wilayah atau lingkungan keluarga. Keputusan perusahaan untuk beroperasi dalam satu atau beberapa wilayah atau seluruh wilayah perlu diberikan perhatian terhadap variasi lokal. Segmentase geografis yang dilihat dalam penelitian ini adalah wilayah persebaran pasar yaitu terdapat dua pasar di Pulau Saparua yakni Pasar Nolot di Kecamatan Saparua Timur dan Pasar Saparua Kota di Kecamatan Saparua.

Menemukan kumpulan objek hingga objek-objek lain dalam satu kelompok yang sama (memiliki hubungan) dengan kelompok yang berbeda (tidak berhubungan) dengan objek dalam kelompok lain sebagai analisis segmen dianalisis dengan analisis cluster (Hermawati, 2013). Analisis cluster bertujuan untuk pengelompokkan objek berdasarkan karakter yang sama diantara objek. Objek seperti produk, benda dan orang. Kemudian objek diklasifikasi dalam satu atau lebih klaster sehingga objek dalam satu klaster tersebut mempunyai kesamaan satu dengan lainnya. Analisis cluster yang dipakai yaitu $k$-means clustering, hasilnya ditampilkan pada Tabel 2. Metode klastering dengan jumlah klasternya diketahui menggunakan metode $k$-means clustering. Jumlah klaster dalam penelitian sebanyak 2 klaster. Berdasarkan output terlihat banyaknya objek di klaster pertama sebanyak 
19 konsumen dan klaster kedua sebanyak 21 konsumen.

Tabel 3. Final Cluster Centers Analisis Segmentasi Pasar pada Dua Klaster

\begin{tabular}{lcc}
\hline \multicolumn{3}{c}{ Final Cluster Centers } \\
\hline \multicolumn{3}{c}{ Ulaster } \\
& 1 & 2 \\
\hline Z-score (Usia) & $-0,60036$ & 0,54318 \\
Z-score (Pendidikan) & 0,80170 & $-0,72534$ \\
Z-score (Pekerjaan) & $-0,33541$ & 0,30346 \\
Z-score (Pendapatan) & 0,60324 & $-0,54579$ \\
\hline
\end{tabular}

Sumber: Analisis Data Primer, 2019

Tabel 3 menunjukkan bahwa data terkait proses standarisasi pada Z-score dengan kemungkinan tanda negatif $(-)$ artinya data di bawah rata-rata total dan tanda positif $(+)$ artinya data di atas rata-rata total. Pada klaster $1, Z$-score bernilai negatif yaitu usia dan pekerjaan sedangkan pada klaster 2, Z-score bernilai negatif yaitu pendidikan dan pendapatan. Hal ini berarti bahwa pada klaster 1, usia dan pekerjaan konsumen masih sangat minim untuk menentukan pilihan dalam memilih sayuran organik untuk dikonsumsi. Hal yang sama juga terjadi di klaster 2, pendidikan dan pendapatan konsumen masih rendah untuk memilih sayuran organik sebagai kebutuhan keluarga konsumen. Setelah terbentuk dua klaster, kemudian dilihat variabel-variabel yang dibentuk klaster memiliki perbedaan pada setiap klaster. Hasil analisis pada nilai $\mathrm{F}$ dan signifikan setiap variabel pada output Anova (Tabel 4).
Tabel 4 menunjukkan semakin besar nilai $\mathrm{F}$ dan angka signifikansinya 0,05 , maka semakin besar perbedaan variabel pada semua variabel. Nilai $F$ terbesar $(56,156)$ terlihat pada Z-score pendidikan, angka signifikan 0,000 berarti signifikansinya nyata. Terlihat bahwa faktor pendidikan berbeda untuk kedua klaster baik untuk klaster 1 maupun klaster 2. Variabel $Z$-score pendapatan yang mempunyai nilai $\mathrm{F}$ 19,375 dan signifikansi 0,000 berarti signifikansinya nyata. Variabel Z-score pekerjaan nilai $\mathrm{F} 4,429$ dan signifikan 0,042 berarti signifikansinya nyata karena $0,042<$ 0,05 . Tabel 4 menampilkan hasil analisis dua klaster yang terbentuk menunjukkan perbedaan berdasarkan karakteristik demografis.

\section{Klaster 1}

Konsumen klaster satu sebanyak 19 orang memiliki karakteristik:

1. Konsumen berusia 21-30 tahun sebanyak 4 orang $(21,05 \%)$, usia 31-40 tahun sebanyak 11 orang $(57,89 \%)$, usia $41-50$ tahun sebanyak 4 orang $(21,05 \%)$. Hal ini berarti bahwa usia 31-40 tahun mempunyai keinginan yang tinggi untuk mengkosumsi sayuran organik dengan alasan meningkatkan daya tahan tubuh dan tetap menjaga kesehatan tubuh.

2. Konsumen berpendidikan SMA berjumlah 3 orang $(15,78 \%)$, berpendidikan D3 dengan jumlah 1 orang $(5,26 \%)$ dan berpendidikan Sarjana berjumlah 15 orang $(78,95 \%)$.

Tabel 4. Nilai Anova

\begin{tabular}{|c|c|c|c|c|c|c|}
\hline \multirow{2}{*}{ Uraian } & \multicolumn{2}{|c|}{ Cluster } & \multicolumn{2}{|c|}{ Error } & \multirow[t]{2}{*}{$F$} & \multirow[t]{2}{*}{ Sig. } \\
\hline & Mean Square & $d f$ & Mean Square & $d f$ & & \\
\hline Z-score (Usia) & 13,044 & 1 & 0,683 & 38 & 19,097 & 0,000 \\
\hline Z-score (Pendidikan) & 23,260 & 1 & 0,414 & 38 & 56,156 & 0,000 \\
\hline Z-score (Pekerjaan) & 4,071 & 1 & 0,919 & 38 & 4,429 & 0,042 \\
\hline Z-score (Pendapatan) & 13,170 & 1 & 0,680 & 38 & 19,375 & 0,000 \\
\hline
\end{tabular}

Sumber: Analisis Data Primer, 2019

Tabel 5. Segmentasi Demografis Konsumen Sayuran Organik

\begin{tabular}{lcc}
\hline \multicolumn{1}{c}{ Karakteristik } & \multicolumn{2}{c}{ Klaster } \\
\cline { 2 - 3 } Demografis & 1 & 2 \\
\hline Usia & $31-40$ tahun & $>50$ tahun \\
Pendidikan & Sarjana & SMA \\
Pekerjaan & PNS & Tukang ojek, Tukang cuci, pensiunan \\
Pendapatan & Rp 1.100.000-2.000.000 & Rp 600.000- 2.000.000
\end{tabular}

Sumber: Analisis Data Primer, 2019 
Terlihat bahwa konsumen yang berpendidikan sarjana lebih banyak karena mereka lebih mengetahui dampak mengkonsumsi sayuran organik bagi kesehatan dibanding sayuran non organik.

3. Pekerjaan konsumen yakni wirausaha berjumlah 3 orang $(15,78 \%)$. Lainnya bekerja sebagai PNS berjumlah 9 orang $(47,37 \%)$, pekerjaan lain-lain sebanyak 5 orang $(26,31 \%)$, responden yang belum bekerja berjumlah 1 orang $(5,26 \%)$, dan yang tidak bekerja berjumlah 1 orang $(5,26 \%)$. PNS lebih banyak membelanjakan uangnya untuk sayuran organik karena setiap bulan mendapatkan penghasilan tetap sehingga mereka lebih dominan untuk mengkonsumsi sayuran organik.

4. Pendapatan konsumen didominasi oleh pendapatan dengan kisaran Rp 1.100 .000 Rp 2.000.000, yakni sebanyak 9 orang $(42,10 \%)$, selebihnya kisaran pendapatan Rp 2.100.000 - Rp 3.000.000 sebanyak 5 orang $(26,31)$, pendapatan lebih dari $\mathrm{Rp}$ 3.000 .000 sebanyak 3 orang $(15,78 \%)$ dan responden yang tidak bekerja sebanyak 2 orang (10,52\%). Hasil penelitian Munandar, 2011 menunjukkan bahwa pelanggan berpendapatan < 1 juta kelas bawah, >1-2,5 juta kelas menengah, dan $>2,5$ juta kelas atas. Pada klaster 1 tingkat pendapatan Rp. 1.100.000-2.000.000 lebih dominan berarti konsumen berada pada kategori berpenghasilan kelas menengah yang membeli sayuran organik.

\section{Klaster 2}

Konsumen klaster dua berjumlah 21 orang memiliki karakteristik:

1. Usia konsumen didominasi oleh usia tua yaitu usia lebih dari 50 tahun 8 orang $(38,09 \%)$, usia $41-50$ tahun hanya 8 orang $(38,09 \%)$, usia $31-40$ tahun 4 orang $(19,04 \%)$, dan usia 21-30 tahun hanya 1 orang $(4,76 \%)$. Konsumen berusia diatas 50 tahun beranggapan bahwa selama ini mengkonsumsi sayuran non organik mereka tetap sehat dan awet sehingga klaster ini lebih cenderung konsumen berusia lebih dari 50 tahun.

2. Konsumen berpendidikan SMP 6 orang $(28,57 \%)$, berpendidikan SD berjumlah 4 orang $(19,05 \%)$, dan berpendidikan SMA berjumlah 11 orang (52,38\%). Pada klaster ini konsumen tidak berpendidikan sampai D3 dan sarjana sehingga tingkatan pendidikan SMA lebih dominan berada di pasar untuk membeli sayuran organik.

3. Pekerjaan konsumen didominasi oleh pekerjaan lainnya tukang ojek, tukang cuci dan pensiunan sebanyak 11 orang $(52,38 \%)$, responden yang memiliki pekerjaan wirausaha 8 orang $(38,09 \%)$, pekerjaan sebagai PNS 1 orang $(4,76 \%)$ dan responden yang tidak bekerja hanya 1 orang $(4,76 \%)$. Kosumen yang dijumpai di pasar adalah berprofesi sebagai tukang ojek, tukang cuci dan pensiunan dan sering ke pasar dan membeli sayuran organik.

4. Pendapatan konsumen didominasi pada kisaran Rp 600.000 - Rp 1.000 .000 berjumlah 10 orang $(47,62 \%)$, responden berpendapatan < Rp 500.000 berjumlah 5 orang $(23,80 \%)$, responden berpendapatan Rp 2.100.000 - Rp 3.000 .000 berjumlah 5 orang $(23,81 \%)$, responden tidak bekerja hanya 1 orang saja $(4,76 \%)$. Pada klaster ini terlihat bahwa tingkat pendapatan konsumen berada pada kategori kelas bawah yakni kurang dari 1.000.000. konsumen tidak terlalu tertarik untuk membeli sayuran organik dengan kondisi pendapatan yang relatif rendah. Karena menurut mereka apapun sayurannya yang panting bisa didapatkan untuk dikonsumsi.

Penelitian ini sejalan dengan penelitian Hermis dan Lubis (2014) yang menyatakan bahwa segmentasi demografi konsumen donat kentang lebih banyak berjenis kelamin perempuan, berumur diantara 21-25 tahun, memiliki tingkat pendidikan S1, dan memiliki pendapatan antara Rp. 500.0001.500.000/bulan. Menurut Aufanada et al. (2017) konsumen memberikan penilaian terbaik terhadap produk sayuran organik. Konsumen bersedia membayar lebih tinggi dari harga yang berlaku saat ini untuk memperoleh sayuran organik. Konsumen bersedia membayar dipengaruhi oleh tingkat pendidikan, pendapatan dan kualitas produk. Semakin tinggi tingkat pendidikan, pendapatan dan penilaian konsumen terhadap kualitas sayuran organik maka kesediaan konsumen untuk membayar semakin meningkat. Perluasan 
penyebaran produk sayuran organik perlu didukung oleh penyebaran informasi tentang manfaat produk pangan organik bagi kesehatan dan lingkungan hidup kepada seluruh lapisan masyarakat. Oleh sebab itu diharapkan adanya kepedulian konsumen terhadap kesehatan diri dan lingkungan yang semakin meningkat dan pasar produk pangan organik akan semakin berkembang.

\section{KESIMPULAN DAN SARAN}

Analisis final cluster menunjukkan bahwa klaster 1, Z-score bernilai negatif yaitu usia dan pekerjaan sedangkan pada klaster 2, Z-score bernilai negatif yaitu pendidikan dan pendapatan. Hal ini berarti bahwa pada klaster 1, usia dan pekerjaan konsumen masih sangat minim untuk menentukan pilihan dalam memilih sayuran organik untuk dikonsumsi. Hal yang sama juga terjadi di klaster 2, pendidikan dan pendapatan konsumen masih rendah untuk memilih sayuran organik sebagai kebutuhan konsumen. Nilai $\mathrm{F}$ terbesar $(56,156)$ terlihat pada Z-score pendidikan, dengan angka signifikan 0,000 yang berarti signifikansinya adalah nyata. Hal ini berarti faktor pendidikan sangat membedakan karakteristik kedua klaster. Atau dapat dikatakan bahwa pendidikan pada kedua klaster yang sangat berbeda antara klaster 1 dengan klaster 2.

Permintaan konsumen terhadap sayuran organik yang terus mengalami peningkatan perlu ditunjang oleh produksi yang kontinu. Konsumen tersegmentasi berdasarkan segemen geografis dan demografis sehingga diperlukan perhatian serius dari semua pihak untuk tetap menjaga ketersediaan sayuran organik di pasar.

\section{DAFTAR PUSTAKA}

Aufanada, V., Ekowati, T., DAN Prastiwi, W. D. 2017. Kesediaan Membayar Produk Sayuran Organik di Pasar Modern Jakarta Selatan. AGRARIS: Journal of Agribusiness and Rural Development Research, 3(2), 68-75.

Bina, E. 2014. Segmen Pasar, Preferensi Dan Persepsi Konsumen Terhadap 4p's Sayuran Organik (Skripsi). Bogor: Institut Pertanian Bogor.
BKKBN. 2014. Kerjasama Pendidikan Kependudukan Jalur non Formal. Jakarta: Direktorat Kerjasama Pendidikan kependudukan.

Dinas Pertanian dan Peternakan Kabupaten Maluku Tengah. 2015. Statistik Kabupaten Maluku Tengah. Masohi: Dinas Pertanian dan Peternakan Kabupaten Maluku Tengah.

Hermawati, F. A. 2013. Data Mining. Yogyakarta: Andi Publisher.

Hermis, Z dan Lubis, S. N. I. 2015. Analisis Segmentasi Pasar Donat Kentang (Studi Kasus Kecamatan Medan Baru, Kota Medan). Journal on Social Economic Of Agriculture And Agribusiness, 4(1).

Kang, J., Haesun, dan Park-Poaps. 2010. Hedonic and Utilitarian Shopping Motivations of Fashion Leadership. Louisiana: Louisaana State University.

Kriyantono, R. 2006. Teknis Praktis Riset Komunikasi. Jakarta: Penerbit Kencana.

Lamb, C. W., Hair, J. F, dan McDaniel, C. 2001. Pemasaran. Edisi pertama. Jakarta: Salemba Empat.

Manuhutu, M. 2005. Menanam Sayuran Organik Bersama Melly Manuhutu. Yogyakarta: Agromedia Pustaka.

Muljaningsih, S. 2011. Preferensi Konsumen dan Produsen Produk Organik di Indonesia. Wacana, 14(4), 1-5.

Perdana. 2016. Faktor-Faktor Yang Mempengaruhi Produktivitas. Jepara: Rajawali Persada.

Ravindra, S. H. 2017. Analisis Pengaruh Strategi Segmenting, Targeting dan Positioning Terhadap Keputusan Pelanggan Membeli Nu Green Tea. Jurnal Ekonomika Dan Manajemen, 6(1), 28-43.

Saragih, S. 2008. Pertanian Organik Solusi Hidup Harmoni dan Berkelanjutan. Jakarta: Penebar Swadaya. 
Jozias, V., Timisela, N. R., Lawalata, M. : Analisis Segmentasi Pasar Sayuran Organik ...

Sudarman. 1999. Teori Ekonomi Mikro. Yogyakarta: BPFE UGM.

Sugiyono. 2018. Statistik Nonparametris Untuk Penelitian. Bandung: Alfabeta.

Suhardjo. 1996. Berbagai Cara Pendidikan Gizi. Yogyakarta: Bumi Aksara.

Sukirno, S. 2008. Teori Pengantar Makroekonomi edisi 3. Yogyakarta: Raja Grafindo Persada.

Sukmaningrum, A., dan Imron, A. 2017. Memanfaatkan Usia Produktif dengan Usaha Kreatif Industri Pembuatan Kaos pada Remaja Di Gersik. Paradigma, 5(3), 1-6.
Timisela, N. R., Leatemia, E. D., dan Polnaya F. 2018. Supply Chain Sayuran Organik di Kota Ambon. Prosiding Seminar Nasional Hasil Penelitian Dan Pengembangan Kepada Masyarakat Universitas Negeri Surabaya, 1(1), 637645.

Todaro, M. P. 1998. Pembangunan Ekonomi Di Dunia Ketiga. Yogyakarta: Erlangga.

Zimbardo. 2000. Psychology and Life. Illinois: Scott Foresman and Company. 